\title{
DISTINGUISHING THE JUMPING SPIDERS ERIS MILITARIS AND ERIS FLAVA IN NORTH AMERICA (ARANEAE: SALTICIDAE)*
}

\author{
By Wayne MADDISON \\ Museum of Comparative Zoology, \\ Harvard University, \\ Cambridge, Massachusetts 02138
}

The jumping spiders now identified as Eris marginata are among the most frequently encountered in North America, for they are common on trees, shrubs and herbs throughout much of the continent. However, two species have been confused under this name. One is an abundant transamerican species whose proper name is Eris militaris; the other is Eris flava, widely distributed in eastern North America though common only in the southeast. In this paper I describe how they may be distinguished. The abbreviation MCZ refers to the Museum of Comparative Zoology; ZMB to the Zoologisches Museum, Humboldt-Universität zu Berlin.

\section{Eris militaris (Hentz), NEW COMBINATION Figures 2-7, 14}

Attus militaris Hentz 1845: 201, pl. xvii, fig. 10ᄋ, 11ठิ. Type material lost or destroyed (see Remarks, below), from North Carolina and Alabama. Neotype here

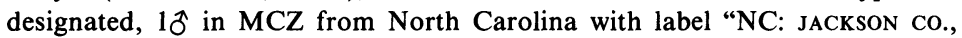
Coyle Farm, $1.5 \mathrm{mi} \mathrm{SW}$ of Webster, 7 Sept. 1975; F. Coyle."

Plexippus albovittatus C. L. Koch 1846: 118, fig. 1178ㅇ․ Syntypes in ZMB 1 \% with labels "P. albovittatus 1739" and "1739", and 1 \% with label "P. albovittatus ZMB 1739", examined. Type locality Pennsylvania (Koch, 1846). NEW SYNONYMY.

Eris aurigera C. L. Koch 1846: 189, fig. 1237ð̂. Syntypes in ZMB $1 \hat{\sigma}$ with carapace and abdomen in alcohol with labels "Eris aurigera C. L. Koch*, 1774" and "Typus" and remaining body parts mounted on cover slip in small box with label "(Eris aurigera Koch*) Dendryphantes marginatus Walck., ZMB 1774a, D. militaris Hentz, XI, Syntypus" and $1 \hat{\delta}$ mounted on cover slip with label "Eris aurigera*, C. L. Koch, ô Rf.?, 1774b, Syntyp., Paraphidippus”, both examined. Euophrys humilis C. L. Koch 1846: 217, fig. 1262ㅇ. Holotype 1 i in ZMB with labels "Holotypus", "1804", “ZU 1804", "Euophrys humilis", "Pennsylvanien, Zimmermann leg.", "Zool. Mus. Berlin", examined.

Manuscript received by the editor January 15, 1986. 
Icius albovittatus Keyserling 1884: 502, fig. 10․ Syntypes 191 immature in MCZ with labels "15 Icius albovittatus Keys., $\&$ Massachusetts", "15", examined. (Junior homonym of Icius albovittatus Keyserling, 1883.)

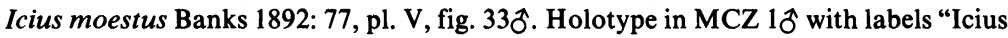
moestus Bks", "Dendryphantes moestus Bks type", "Ithaca, N.Y.", "Nathan Banks Coll.", examined.

Dendryphantes marginatus:-Simon 1901: 624 (not Attus marginatus Walckenaer; see Remarks below).

Dendryphantes louisianus Chamberlin 1924: 34, fig. 519. Holotype in MCZ 1ㅇt해 label "Dendryphantes louisianus Ch. ㅇ Type, La.: Kenner, R. V. Chamberlin Coll.", examined.

Phidippus molinor Chamberlin 1925: 133, fig. 49․ Holotype in MCZ 19 with label "Dendryphantes molinor Chamb., $\$$ holotype, Utah: Mill Creek Canyon, R. V. Chamberlin Coll. 1071", examined.

Paraphidippus marginatus:-Chickering 1944: 180 (in part), figs. 78-82.

Paraphidippus marginatus:-Kaston, 1948: 479.

Eris marginata:-Kaston 1973: 118 (in part), figs. 51-54.

Remarks on synonymy: It is unfortunate that most workers since about 1930 have accepted without question Simon's (1901: 624) synonymy of Attus militaris Hentz 1845 with Attus marginatus Walckenaer 1837, for the synonymy is incorrect: Walckenaer's original description (p. 466) and Abbot's figure (number 444) clearly refer to Hentzia palmarum (Hentz). Walckenaer refers to an elongate abdomen, a fawn-brown first pair of legs, yellow posterior legs, and chelicerae elongate and held in front, whereas Eris militaris has an abdomen of typical width, posterior legs strongly marked with dark brown, and chelicerae robust and divergent. Abbot's drawing (see Figure 1), on which Walckenaer based his description of $A$. marginatus, unambiguously portrays a male Hentzia palmarum, given that his specimen was from Georgia. Because the name marginatus is inappropriate for the transamerican Eris species, another name must be used. The type material for the next oldest name, Attus militaris, is apparently lost or destroyed. Burgess (1875, vii) said that only 60 specimens glued on cards remained of Hentz's collections, the remainder having been destroyed. The surviving specimens were in the collection of the Boston Society of Natural History, which has subsequently become the Boston Museum of Science. The Museum of Science no longer has these specimens nor any record of them (D. Salvatore, pers. comm.), nor does the MCZ, which received many of the Society's collections. I presume Hentz's types to have been lost or destroyed. Without the type material the interpretation of Attus militaris is not entirely clear, for Hentz's 


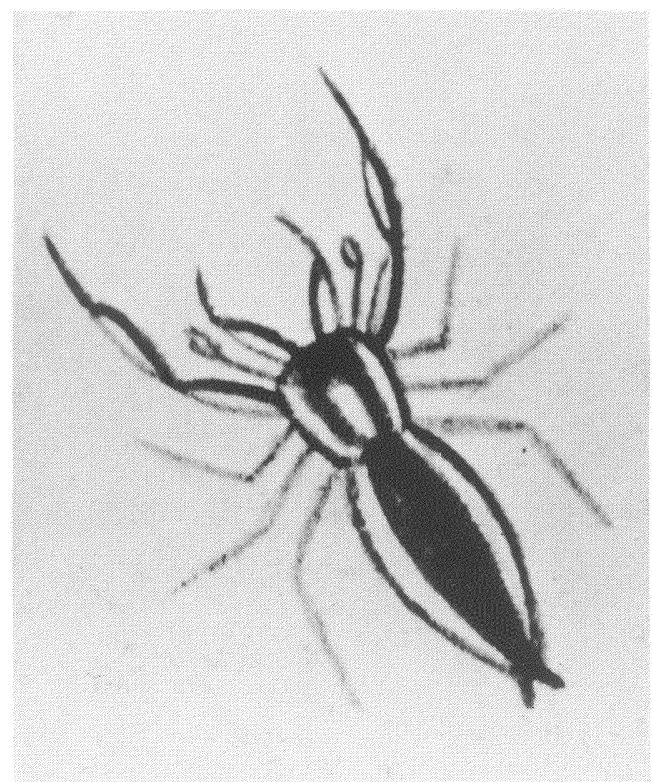

Fig. 1. Abbot's figure 444 on which Walckenaer (1837) based his description of Attus marginatus. Abbot's legend reads "444. Aranea. Taken 4th April, two upon a Myrtle on the side of a Pond in the Oak Woods of Burke County. Rare." From a color slide taken by Allen Brady of Abbot's (1792) original in the British Museum (Natural History).

1845 description might refer to either the transamerican or the eastern species. Still, his failure to describe a white marginal band in the male, and his illustration showing a dark femur on the male palp (better seen in his original color drawing) both suggest that he had the transamerican species. Therefore, I have designated a male of this species as neotype for Attus militaris. This is advantageous for nomenclatural stability, for Hentz's name was the only name commonly used before 1930 for the abundant transamerican species. In contrast, I have been unable to find any use of Koch's names albovittatus, aurigera, and humilis since 1864, except in synonymies and catalogues.

Male carapace margin and clypeus brown (Fig. 7), without white scales, or if the clypeus has white scales, then they only rarely extend along margin past palps. Longitudinal white bands extending back 

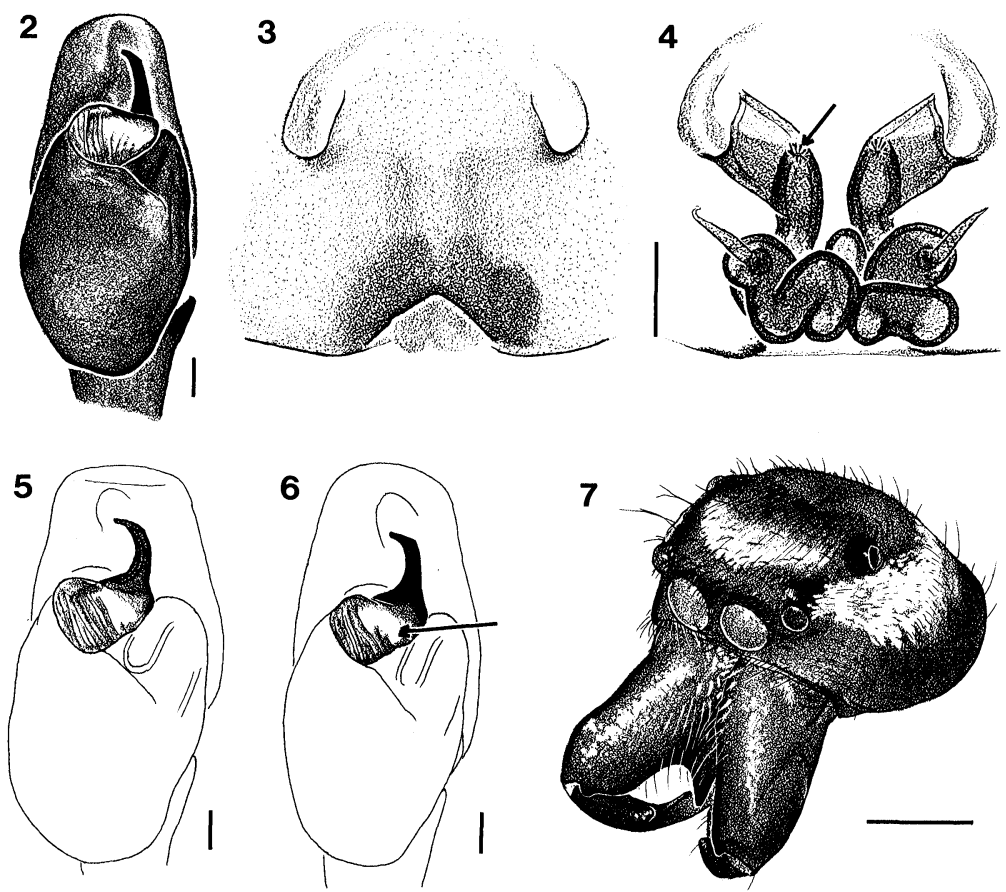

Figs. 2-7. Eris militaris 2. Left palp, ventral view (Port Elgin, Ontario). 3. Epigynum, ventral view (Dwight, Ontario). 4. Cleared epigynum, dorsal view (Dwight, Ontario); arrow shows flowerlike gland opening. 5. Left palp, oblique view from the ventral-retrolateral-distal (Pine Lake, Michigan), and 6. Same (Forsyth, Georgia); arrow shows lack of wrinkles on retrolateral half of embolar base. 7. Male carapace and chelicerae (Walloon Lake, Michigan), oblique view. Scale bars $0.1 \mathrm{~mm}$ for $2-6 ; 1 \mathrm{~mm}$ for 7 .

from anterior lateral eyes usually broad. Palp femur and patella as dark as the more distal segments. Embolus shorter and stouter, and more broadly joined to the embolar base (Figs. 5,6 ) than in flava. Wrinkles on the ventral surface of the embolar base usually straight, and absent from the retrolateral half (Figs. 2, 5, 6; see arrow in Fig. 6).

Female carapace generally with a continuous covering of white scales above margin beneath anterior lateral eyes. Epigynal openings usually smaller and more laterally facing (Fig. 3) than in flava. 

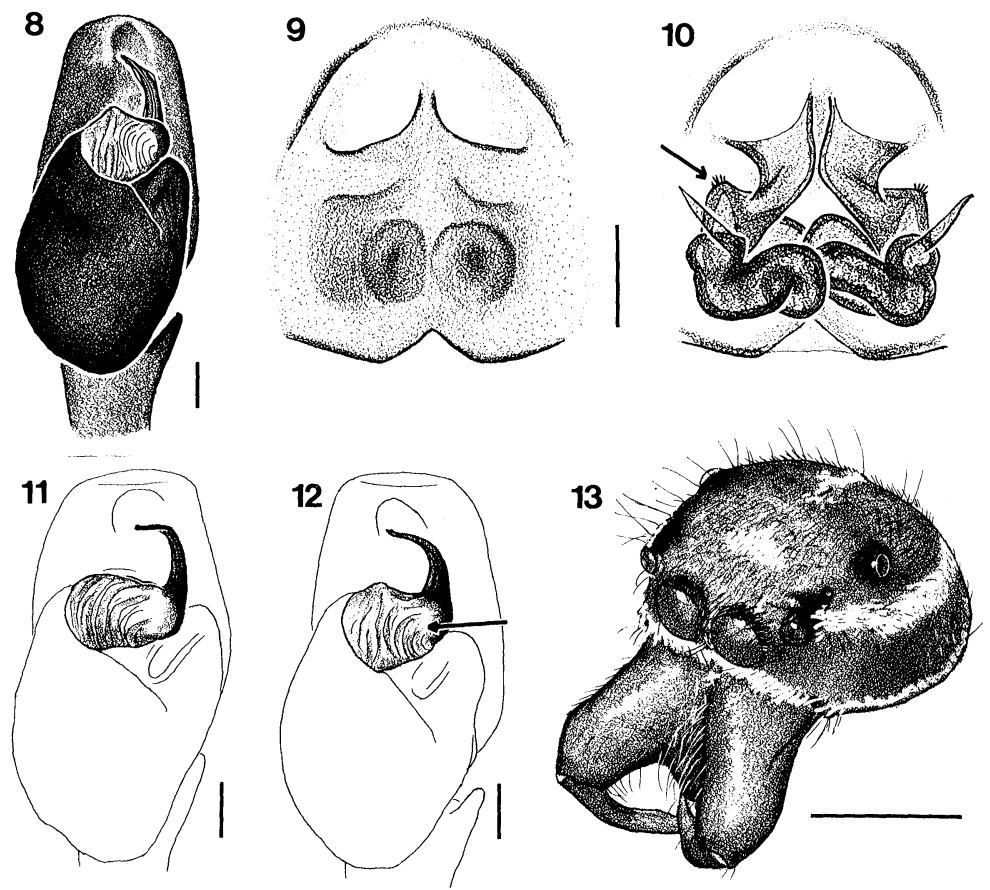

Figs. 8-13. Eris flava 8. Left palp, ventral view (Florida City, Florida). 9. Epigynum, ventral view (Point Pelee, Ontario). 10. Cleared epigynum, dorsal view (Point Pelee, Ontario); arrow shows flowerlike gland opening. 11. Left palp, oblique view from the ventral-retrolateral-distal (Pine Lake, Michigan), and 12. Same (Florida City, Florida); arrow shows curled wrinkles on retrolateral half of embolar base. 13. Male carapace and chelicerae (S. of St. Joseph, Michigan), oblique view. Scale bars $0.1 \mathrm{~mm}$ for $8-12 ; 1 \mathrm{~mm}$ for 13 .

Each duct proceeds medially to a flower-like structure (apparently gland openings; see arrow in Fig. 4), then posteriorly.

Habitat varied; common on trees and shrubs. Distribution shown in Fig. 14.

\section{Eris flava (Peckham and Peckham) \\ Figures 8-13, 15}

Dendryphantes flavus Peckham \& Peckham 1888: 39, pl. I, fig. 27우, pl. III, figs. 27, 27aㅇ. Syntypes in MCZ 3우, 1 immature $ᄋ$ with label "Dendryphantes flavus 


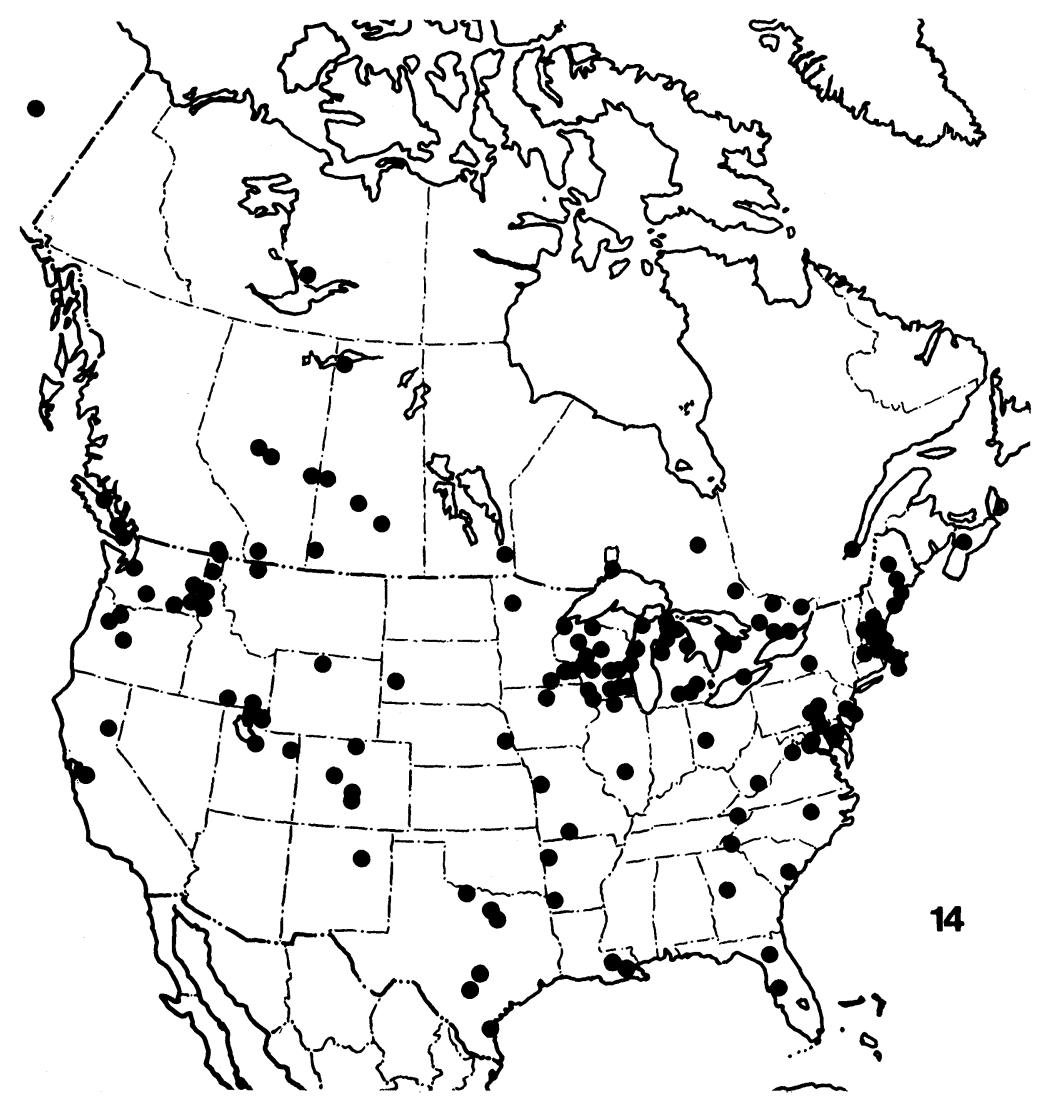

Fig. 14. Distribution of Eris militaris.

Pkm., 1888. New York. Type. $\$ ”$, examined. Type vial also contains one immature Phidippus.

Dendryphantes armatus Banks 1909: 167, fig. 5ô. Syntypes in MCZ $7 \hat{\sigma}$ with labels "S. de las Vegas, Cuba 10-17. 07", Dendryphantes armatus Bks.", "type”, "D. militaris H, armatus B, Cuba", "Nathan Banks Coll.", examined. NEW SYNONYMY.

Paraphidippus militaris:-Bryant 1940: 502.

Paraphidippus marginatus:-Chickering 1944: 180 (in part).

Eris marginata:-Kaston 1973: 118 (in part).

Eris flava:-Kaston 1973: 120, figs. 66-67.

Remarks on synonymy: Eris flava was thought to be an uncommonly collected species known only from females (Kaston, 1973). 
While less common than militaris, many males are available in collections (including the Peckham and Banks collections), identified as militaris or marginata. Chickering's Michigan collections are mixed E. militaris and E. flava. Though most of Kaston's identifications were correct, at least some Floridian males he identified as E. marginata prior to his 1973 paper are E. flava.

Male carapace with marginal band of white scales extending across clypeus (Fig. 13) and usually back well past the palps. Longitudinal white bands extending back from ALE usually narrower than in militaris. Palp femur and often patella distinctly paler than more distal segments. Embolus longer and thinner than in militaris, arising more abruptly and more directly behind the embolar base (Figs. 11, 12). Wrinkles on embolar base, especially the more retrolateral ones, are distally curled retrolaterally (Figs. 8, 11, 12; see arrow in Fig. 12).

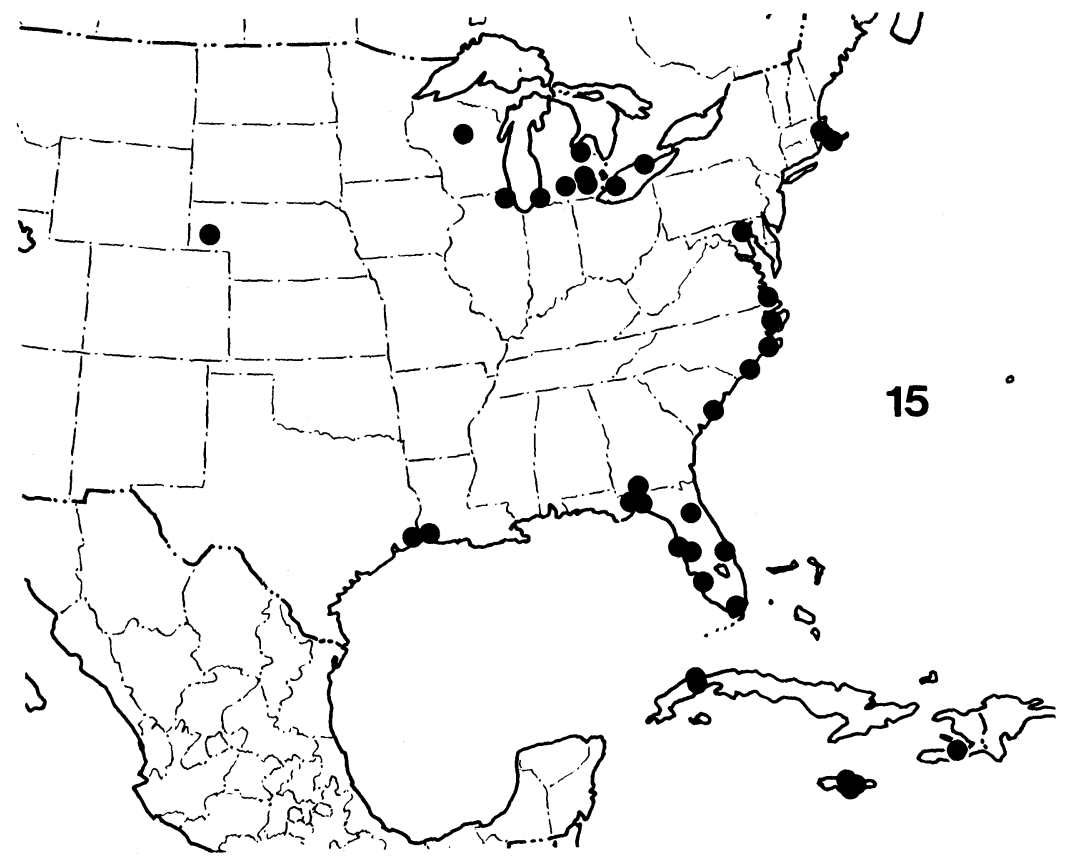

Fig. 15. Distribution of Eris flava. The specimen from the North Platte River at Bridgeport, Nebraska was collected by me, and the identification checked carefully. 
Female carapace with patch barren of scales just above the marginal white band at a point below anterior lateral eyes. Epigynal openings wider and face more anteriorly (Fig. 9) than in militaris. Each duct first proceeds posteriorly and then laterally to the flowerlike structure (Fig. 10, arrow), then posteriorly. The epigynal ducts are the best distinguishing feature.

Habitat information is sparse, but the species appears to prefer marshes and fields. Found in cedar swamp (Mass.), sweeping grass and herbs near river (Nebr.), on vegetation in marshy area (Ont.), meadow (Ill.), on Nelumbo lutea and in fields (Fla.). Distribution shown in Fig. 15.

\section{ACKNOWLEDGEMENTS}

All but a few of the specimens examined are in the MCZ. The types of Koch names were kindly loaned by M. Moritz and S. Fischer of the ZMB. For the loan of the remaining specimens, I thank E. Schlinger and D. Wagner (Essig Museum, University of California, Berkeley) and W. J. Gertsch (American Museum of Natural History). H. W. Levi and D. R. Maddison gave useful comments on the manuscript.

\section{REFERENCES}

Аввот, $\mathbf{J}$.

1792. Drawings of the Insects of Georgia, in America, vol. 14, Spiders. Unpublished manuscript in the British Museum (Natural History) (Copy seen).

BANKS, N.

1892. The spider fauna of the Upper Cayuga Lake Basin. Proc. Acad. Nat. Sci. Philadelphia, 1892: 11-81, 5 pl.

1909. Arachnida of Cuba. Estación central agronómica de Cuba, Second Report, Part II, pp. 150-174.

BRYANT, E. B.

1942. Cuban spiders in the Museum of Comparative Zoology. Bull. Mus. Comp. Zool., 86: 259-532+22 pl.

Burgess, E.

1875. Preface, pages $\mathrm{v}$-xiii, in A collection of the arachnological writings of Nicholas Marcellus Hentz, M. D., Boston Soc. Nat. Hist.

\section{Chamberlin, R. V.}

1924. Descriptions of new American and Chinese spiders, with notes on other Chinese species. Proc. U.S. Nat. Mus., 63(13): 1-38.

1925. New North American spiders. Proc. California Acad. Sci., (4) 14(7): 105-142. 
Chickering, A. M.

1944. The Salticidae (jumping spiders) of Michigan. Papers Michigan Acad. Sci., Arts \& Letters, 29: 139-222.

Hentz, N. M.

1832. On North American spiders. American J. Sci., 21: 99-122.

1845. Descriptions and figures of the Araneides of the United States. Boston J. Nat. Hist., 5: 189-202.

KASTON, B. J.

1948. Spiders of Connecticut. Connecticut State Geol. and Nat. Hist. Survey, 70: $1-874$.

1973. Four new species of Metaphidippus, with notes on related jumping spiders (Araneae: Salticidae) from the eastern and central United States. Trans. Amer. Micros. Soc., 92: 106-122.

KоCH, C. L.

1846. Die Arachniden. Dreizehnter Band. Nürnberg, pp. 1-234.

Peckham, G. W. and E. G. Peckham

1888. Attidae of North America. Trans. Wisconsin Acad. Sci., Arts \& Letters, 7: 3-104.

1909. Revision of the Attidae of North America. Trans. Wisconsin Acad. Sci., Arts \& Letters 16: 355-646.

Simon, E.

1901. Histoire Naturelle des Araignées. Deuxième édition. Tome 2, fasc. 3, pp. 381-668. Paris.

Walckenaer, C. A.

1837. Histoire naturelle des Insectes. Aptères. Tome 1. Paris, pp. 1-682. 

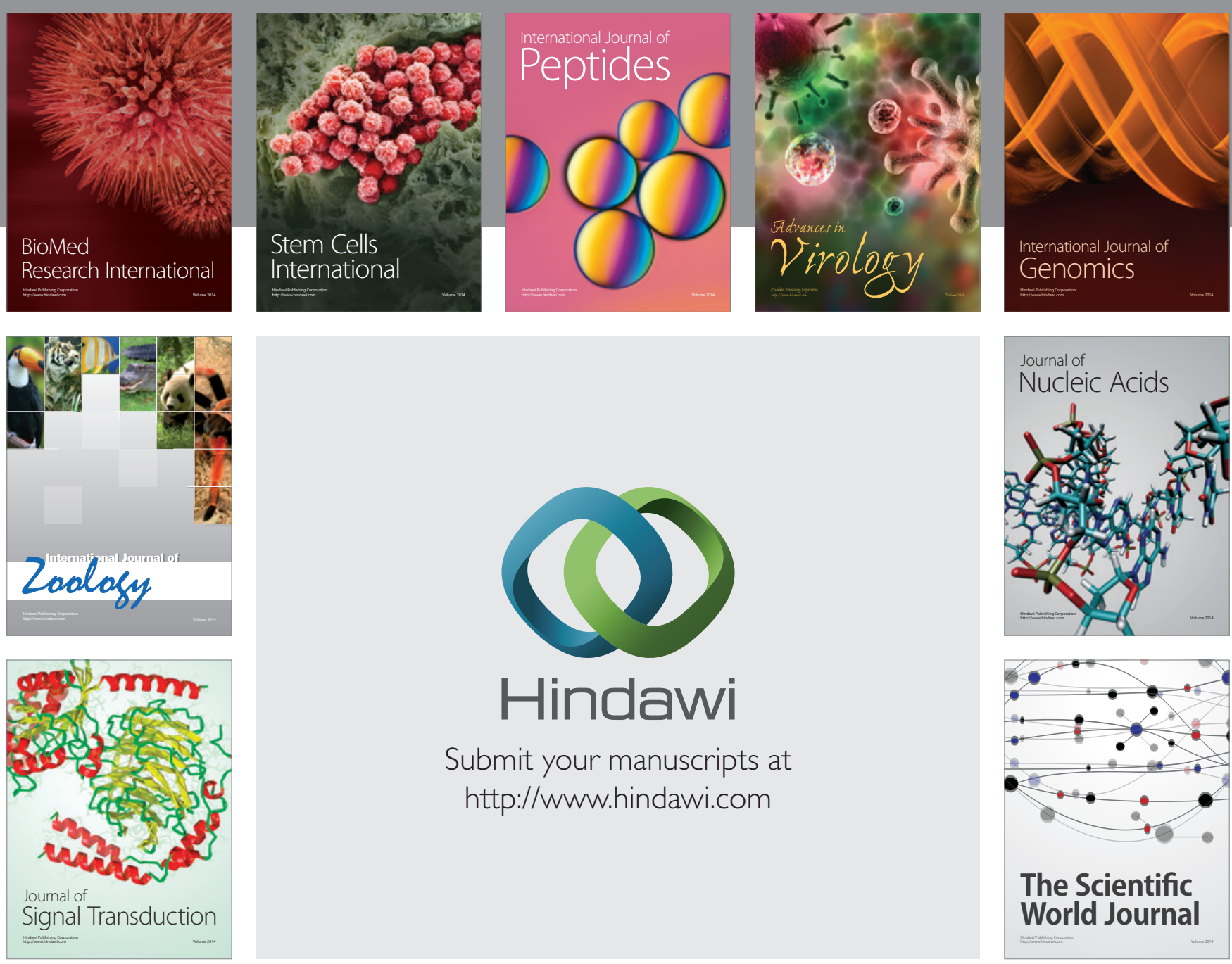

Submit your manuscripts at

http://www.hindawi.com
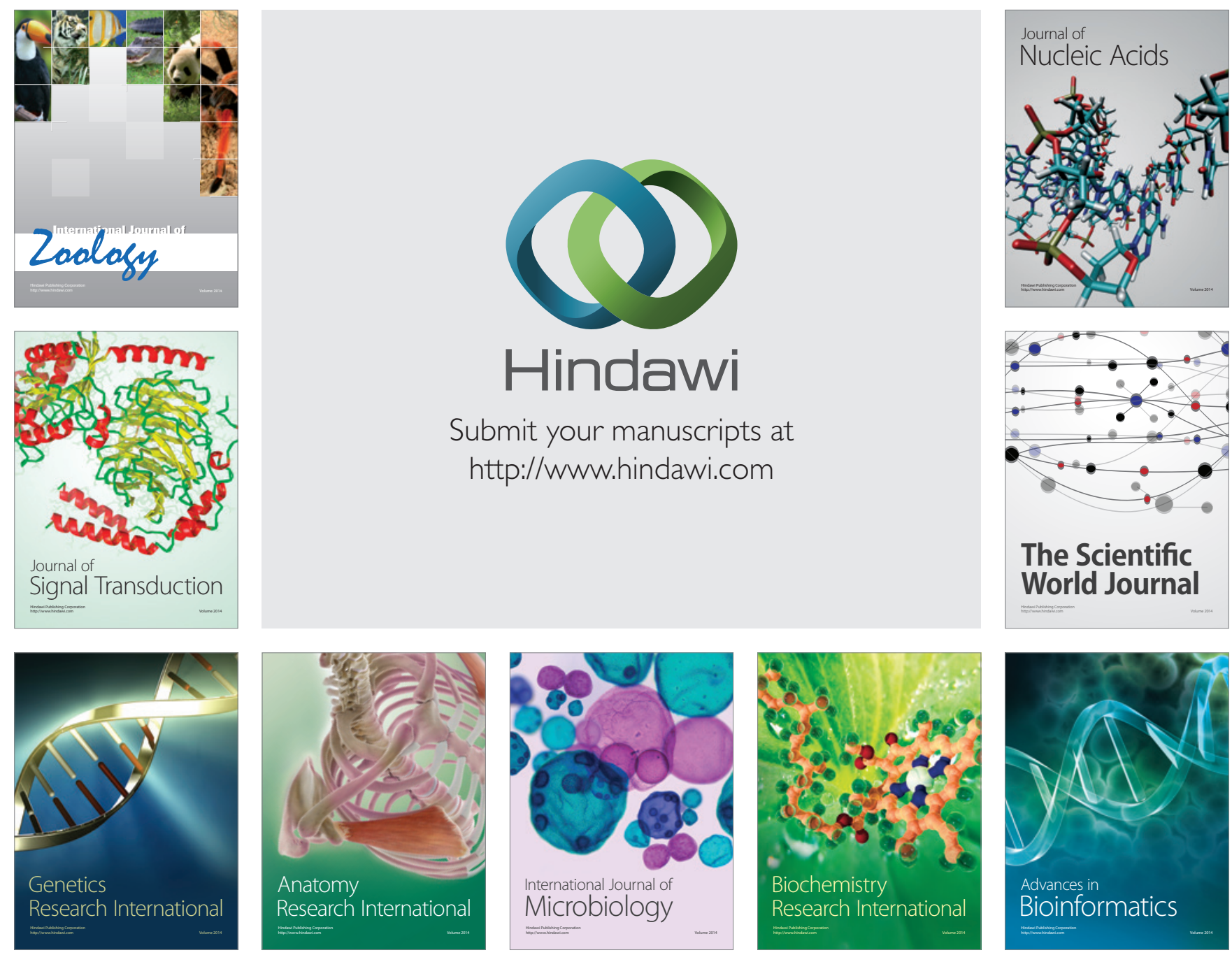

The Scientific World Journal
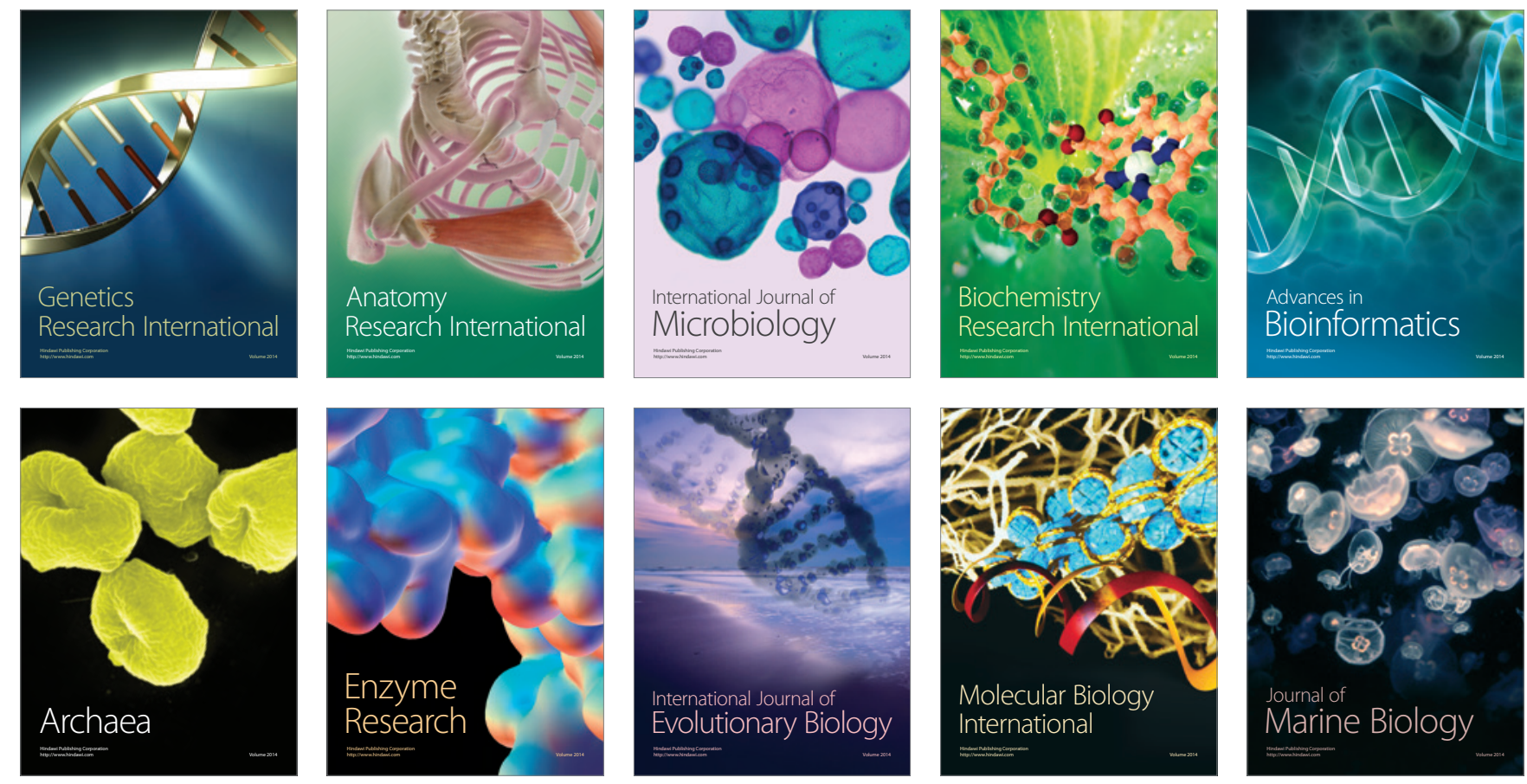